\title{
Corporate Reliance On Bank Loans: Evidence From LISTED Companies In GHANa ${ }^{1}$
}

\author{
J Abor \\ Department of Finance, University of Ghana, Legon
}

\begin{abstract}
This paper examines the incidence of bank financing among Ghanaian listed companies and the determinants of listed firms' reliance on bank borrowing. The empirical results from a regression model reveal that bank loans account for one-third of debt financing. This suggests that bank loans are important in financing Ghanaian listed firms. The results also show that asset structure, growth opportunities and interest rates have significantly positive associations with bank debt ratio, while age of the firm, size of the firm, profitability and firm risk are significantly and negatively related to bank debt ratio. The results generally indicate that bank loans represent an important source of financing Ghanaian listed firms.
\end{abstract}

Keywords: bank loans, debts, financing, Ghana

JEL G30, G32

1

\section{Introduction}

Debt financing represents a major source of financing businesses in Ghana. It constitutes more than half of the total assets of most Ghanaian listed firms (Abor \& Biekpe, 2005). Debt financing comes from two main sources: private debt and public debt offers. Sources of private debt include banks and non-bank private lenders. Bank debt and non-bank private debt differ in terms of the concentration and identity of debt holders, regulatory requirements, maturity, and placement structure. Kwan and Carleton (1995) describe private non-bank loans as being tightly held and relatively illiquid. In addition, private non-bank loans tend to have lower flotation costs than public issues and have custom-designed covenants. The difference between public debt and private bank debt is that, while the ownership of public debt is diffused widely, the ownership of private bank debt rests in the hand of only one lender. This study provides evidence on firms' reliance on bank financing as an alternative source of debt financing. Bank financing may be either a shortterm or long-term loan.
Earlier studies posit that private debt financing has a significant advantage over public debt in terms of monitoring efficiency (Diamond, 1984; Boyd \& Prescott, 1986; Berlin \& Loyes, 1988), access to private information (Fama, 1985), and the efficiency of liquidation and renegotiation in financial distress (Gertner \& Scharfstein, 1991; Chemmanur \& Fulghieri, 1994). However, Rajan (1992) argues that private lenders can also affect the borrower negatively by extracting rents and distorting management incentives. Previous empirical studies identified bank debt as a major source of financing businesses (see Houston \& James, 1996; Krishnaswami et al., 1999; Cantillo \& Wright, 2000). Banks make a wide variety of loans to a wide variety of customers for many different purposes. Several factors determine the growth and mix of a bank's loan portfolio, including the characteristics of the market area the bank serves, the size of the bank, the experience and expertise of the bank in making different types of loans; the bank's official loan policy and the expected yield to the bank, as compared to the yield on all other assets the bank can acquire. 
In spite of the importance of banks as a source of debt finance, academic interest in the topic has focused mainly on developed economies. This present study contributes to the literature within a developing country context. The study examines the determinants of banking loans of firms listed on the Ghana Stock Exchange (GSE). This is a gap which this current paper seeks to address. The rest of the paper is organised as follows. Section two gives a review of the extant literature on the subject. Section three describes the data and justifies the choice of the variables used in the analysis. The model used in the analysis is then estimated. Section four presents and discusses the results of the empirical analysis. Finally, section five summarises the findings of the study.

\subsection{Overview of the Ghanaian banking system}

Prior to 1983 the Ghanaian banking system was mainly dominated by the state-owned banks. The only two foreign banks, Barclays Bank and Standard Chartered Bank, were seen to favour well-established foreign firms and to neglect indigenous farmers and small entrepreneurs in granting loans and advances. Subsequently, the financing needs of specific sectors were addressed by establishing state-owned development banks: the National Investment Bank (1963), the Agricultural Development Bank (1965), and the Bank for Housing and Construction (1973). The Bank of Ghana was established in 1957 to supervise all other banks (replacing the role of the West African Currency Board). Government's interest to further increase firms' access to finance led to the establishment of specialised banks: the Cooperative Bank, the National Savings and Credit Bank, the Social Security Bank, and rural unit banks (Aryeetey, 2001).

Under the World Bank-funded Financial Sector Adjustment Programme (FINSAP) the Ghanaian Banking Law was amended to provide a stronger prudential base in terms of minimum capital, reporting and lending guidelines. Entry of new banks and non-bank financial institutions was encouraged, especially through new laws in 1993 , to support the development of leasing, housing finance, and nine categories of non-bank financial institutions. The main areas of the reform included interest rate liberalisation, removal of credit ceilings and other quantitative controls, restructuring and re-capitalisation of banks, privatisation of state-owned banks, regulation and supervision, development of money and capital markets and support for informal finance and microfinance.

The FINSAP also resulted in the establishment of a stock exchange. The Ghana Stock Exchange was established in 1990 to serve as a market for public trading in equities and bonds. The stock market also facilitates the mobilisation of long-term capital for companies. The exchange started with 12 companies considered to be the best performers in the country. Since its inception, a total of 15 IPOs and 12 rights issues have been raised, representing a total value of $\notin 473.47$ billion and @255.92 billion respectively. It currently has 29 listed companies and 3 corporate bonds. All types of securities can be listed; criteria for listing include capital adequacy, profitability, spread of shares, years of existence and managerial efficiency. The manufacturing and brewing sectors dominate the exchange. Most of the listed firms are Ghanaian, but there are some multinationals.

The formal banking sector in Ghana currently comprises the central Bank of Ghana (BOG) which supervises the operations of the banking sector and about 19 other banks with 6 foreign banks, which are engaged in lending to customers in both the private and public sectors. Banks were previously established to provide specialised banking services such as commercial banking, development banking, merchant banking etc. However, with the recent introduction of the Universal Banking License, banks are permitted to operate in all fields of banking. The Ghanaian banking sector seems to be dominated by a few banks (i.e. Ghana Commercial Bank, Barclays Bank and Standard Chartered Bank), holding about 55 per cent of total assets of the banking sector. Ghana Commercial Bank holds about 25 per cent of total assets and 20 per cent of deposits. The other banks tend to operate on a much smaller 
scale. About 35 per cent of bank branches are located in the capital region (Greater Accra), even though this region represents less than 13 per cent of the country's population. About half of all bank branches in the interior belong to Ghana Commercial Bank (Buchs \& Mathisen, 2003).

The banking sector grew rapidly (as measured by the aggregated total-assets-to-GDP ratio) between 1996 and 2000, reflecting partly financial deepening as well as loose monetary conditions. However, in 2001 the sector experienced tight monetary policy, resulting in a situation where domestic credit to the private sector stayed as low as 10 per cent of GDP. This reflects in part a typical crowding-out effect, as most of the banks' resources were absorbed by the public sector, either in the form of loans to state-owned enterprises or holdings of government securities, which led to very high real T-bill yields. As of September 2002, net loans constituted about 38 per cent of total assets, as banks preferred to invest their resources in liquid, low-risk assets such as government securities, the later constituting 25 per cent of total assets. In addition, state-owned enterprises also attracted sizeable amounts of direct lending from commercial banks, thereby worsening the crowding-out effect. The resources available for lending to the private sector (about 29 per cent of total assets in 2002) were mainly channelled to the manufacturing sector ( 23 per cent of total credit), followed by commerce and finance (14 per cent), services (12 per cent), and construction (less than 9 per cent), while the agriculture, forestry, and fishing sectors received less than one-tenth of total bank credit, although agriculture accounts for 36 per cent of GDP (Buchs \& Mathisen, 2003).

Important policy moves by the Bank of Ghana in 2005 were the revision of the prime rate downwards from 18.5 per cent to 16.5 per cent in May and the reduction in the secondary reserve for banks from 35 per cent to 15 per cent in June. The volume of government's issued securities continued falling, as did the rates. The main reasons for the falling rates are the signal from the prime rate and the dwindling of the public sector borrowing requirement. These recent developments in the Ghanaian banking industry will certainly make more money available for banks to expand private sector lending.

\section{2}

\section{Literature review}

The theory of financing choice focuses on several determining factors: differential taxation of income from different sources, bankruptcy cost/risks, the agency problem, informational asymmetries, and signalling theory. First, taxation will encourage debt financing, provided the interest paid on the debt is tax deductible. Since payment with respect to equity financing such as dividend is not tax deductible, the tax effect is likely to bias the financing choice towards debt, as more debt increases the aftertax proceeds to the owners (Modigliani \& Miller, 1963; Miller, 1977). Second, if firms increase their debt position as a result of the tax benefit indicated above, then their ability to meet their fixed interest payment obligation reduces. Such a situation increases the probability (risk) of bankruptcy and consequently the cost of financing. Firms that adjust their capital structure away from excessive debt reduce the risk of exposure of debt-equity mix and thus lower their cost of finance (Agarwal \& Mohtadi, 2004). Third, the agency problem arises as a result of the relationships between shareholders and managers and those between debt-holders and shareholders (Jensen \& Meckling, 1976). According to Harris and Raviv (1990), the conflict between shareholders and managers arises because shareholders hold the entire residual claim and consequently managers do not capture the entire gain from their profit-enhancing activities, but they do bear the entire cost of these activities. On the other hand, the conflict between debt-holders and shareholders is due to moral hazard. The conflict arises because equity-holders have an incentive to invest suboptimally in very risky projects (Jensen \& Meckling, 1976).

Fourth, the concept of financing choice is also explained within the context of informational asymmetries. The existence of information asymmetries between the firm and likely 
finance providers causes the relative costs of finance to vary between the different sources of finance. For instance, an internal source of finance, where the funds provider is the firm, will have more information about the firm than external finance via debt, thus external finance providers will expect a higher rate of return on their investments. This means that it will cost the firm more to use external debt finance than internal funds (Myers \& Majluf, 1984). The conclusion drawn from the asymmetric information theory is that there is a hierarchy of firms' preferences with respect to the financing of their investments (Myers, 1984; Myers \& Majluf, 1984). This "pecking order" theory suggests that firms will initially rely on internally generated funds (i.e. retained earnings), where there is no existence of information asymmetry, they will then turn to debt if additional funds are needed and finally, they will issue equity to cover any remaining capital requirements. Fifth, the signalling theory suggests that, if a firm issues debt, it indicates the firm has an investment opportunity that exceeds its internally generated funds. So, changes in the capital structure often serve as a signal to outsiders about the current situation of the firm as well as the managerial expectations concerning future earnings. The debt offering is believed to reveal information the management of a firm is expecting about future cash flows if it will cover the debt costs. However, the bankruptcy fears still impact on the signal and intensify the cost of this signal (Asquith \& Mullins, 1986; Eckbo, 1986).

In addition to these explanations, what does the theory suggest about the role of bank finance in the financing choice of firms? Listed firms are amenable to several financing sources: equity finance, debt finance, or a combination of debt and equity. Bank financing may be either a short-term or a long-term loan. One important issue that arises in the debt choices of most companies is whether to maintain single or multiple bank relationships. Houston and James (1996) insist that maintaining a single bank relationship limits access to funds. Other analysts (Beston \& Smith, 1976; Blackwell \& Kidwell, 1988) also argue that single bank relationships have significant economic benefits, as they reduce issue costs for bank loans, unlike the case with public debts. The single bank relationship facilitates bonding between the lenders and borrowers. The bankclient relationship allows the bank to maintain the confidentiality of proprietary information (Campbell, 1979), monitor the firm more efficiently (Leland \& Pyle, 1977; Diamond, 1984), generate reliable information on the firm (Campbell \& Kracaw, 1980; Fama, 1985), and effect future loan negotiations (Berlin \& Loeys, 1988; Chemmanur \& Fulghieri, 1994).

Since bank reserve requirements impose additional costs on bank borrowing, Fama (1985) posits that there must be something special about bank loans relative to other credit schemes. Several studies on listed real estate companies in the UK did confirm that bank loan financing announcements often led to positive responses in stock prices of these companies. According to these studies, the uniqueness of bank debt is substantiated by several event-studies on stock price responses to announcements involving bank financing. In contrast to the negative or zero excess return associated with other means of raising corporate funds, Mikkelson and Partch (1986), James (1987), Lummer and McConnell (1989), Slovin, et al. (1992), and Brown, et al. (1993) find that stock prices respond positively to announcements involving bank financing.

Houston and James (1996) and Johnson (1997) found important differences between the determinants of bank debt and non-bank debt. In examining the mix of private and public debt employed by US public real estate companies, Houston and James (1996) concentrated on the potential hold-up problem associated with borrowing from a single bank. They found that for firms with a single bank relationship, the level of growth opportunities has an inverse relationship with bank debt ratio. Nevertheless, among firms borrowing from multiple banks, they observed a positive relationship between the bank debt ratio and growth opportunities. Their findings support the position that multiple banking relationships can mitigate the hold-up problem associated with borrowing from a single bank. Their results also revealed that size of the firm and overall leverage are 
negatively related to bank borrowing. This suggests that banks specialise in lending to smaller, less risky firms. Krishnaswami et al. (1999) and Cantillo and Wright (2000) documented a positive relation between growth opportunities and the use of private debt.

In a similar study, Johnson (1997) examined the relationship between several firm characteristics with the proportion of long-term bank debt, long-term private non-bank debt, and long-term public debt in the capital structure of US firms. By partitioning private debt, he was able to show important differences between bank debt and private non-bank debt. He also observed the systematic use of bank debt by firms with access to public debt, which he interpreted to indicate that the benefits attributed to bank debt in theoretical models remain important after the firm has gained access to the public debt markets. He suggested that the firm's choice of debt is influenced by several other factors, such as monitoring and information costs, the likelihood and costs of inefficient liquidation, and the borrower's incentive to take actions which could be harmful to the lender. Ooi (2000) also examined the debt ownership choice of UK property companies. He found that bank borrowing constituted more than half of the total outstanding debt of the quoted property sector. The results of his study also revealed that firm size and credit risk are significant determinants of the bank debt ratio, but the interest rate showed a weakly positive relationship with bank debt ratio.

Following from the findings of these studies on developed economies, a number of factors could be identified as important determinants of bank debt. This present study focuses on the determinant of bank loans among listed firms in Ghana by including other firm level factors discussed in the standard capital structure model, but not included in these previous studies on bank financing. The study also includes macro-economic factors (interest rates and inflation) in explaining the bank financing issue.
3

Methodology

\subsection{Data and variable description}

Empirical analysis of the factors influencing the firm's choice of bank loans is based on a sample of twelve firms listed on the GSE during a fiveyear period, viz.1998-2002. All the companies that were included in the sample fulfilled two basic criteria. First, all the firms were listed on the GSE by 1997. Second, the firms had bank loans on their balance sheets. Data were derived from the published financial statements of the firms during the period 1998-2002.

Variables used for the analysis include bank debt ratio, age of the firm, size of the firm, asset structure, profitability, firm risk, growth opportunities, interest rates, and inflation. Bank debt ratio $(B D R)$ is the percentage of total debt represented in bank loans. This represents the proportion of the total debt that is obtained from banks. It is used as a measure of the importance of bank loans as a source of financing Ghanaian listed firms.

Firm age is included in the model as a proxy for reputation to account for Diamond's (1991) "life cycle" hypothesis concerning the use of bank loans. It is defined as the number of years the firms have been relying on bank loans. Diamond (1989) suggests the use of firm reputation. He interprets reputation as the good name a firm has built up over the years, which is understood by the market and which has observed its ability to meet its obligations in a timely manner. Rajan (1992) argues that a long lending or banking relationship reduces the severity of the informational asymmetries experienced by the bank by providing it with information on the borrowing firm's credit history, its account movements, and the personal behaviour of the firm's manager. Therefore, the expected sign should be positive.

Firm size in the model represents either the largeness or smallness of the firm, using the logarithm of total assets as a measure. Larger firms tend to be more diversified and hence have lower variance of earnings, making them able to tolerate high debt ratios. Smaller firms may find it relatively more costly to resolve 
information asymmetries with lenders, thus they may exhibit lower debt ratios (Titman \& Wessels, 1988; Wald, 1999). Since larger firms are likely to have easier access to bank finance than smaller ones, size is predicted to be positively related to the bank debt ratio of listed companies.

Asset structure is operationalised as tangible fixed assets of the firm divided by total assets. The ratio of tangible fixed assets to total assets is seen as the appropriate measure of asset structure. It is believed that firms that invest heavily in tangible assets tend to have higher financial leverage (Bradley et al., 1984; Titman \& Wessels, 1988; Harris \& Raviv, 1991). High tangible fixed assets imply high collateral value, and this clearly increases the firm's chances of obtaining bank loans. It is therefore hypothesised that a positive relationship between asset structure and bank debt ratio would exist.

Profitability is measured as profit before interest and taxes divided by total assets. Firm profitability is closely related to the pecking order theory. According to this theory, firms will prefer internally generated funds to external financing (Myers, 1984; Myers \& Majluf, 1984). Profitable firms will use their internal funds to finance their operations and investments; thus they will borrow relatively less than firms with low profitability. Therefore a negative relationship between profitability and bank debt ratio is expected.

Risk is usually measured by the variability of earnings. Debt providers are inclined to provide capital to firms whose earnings are stable since earnings uncertainty increases the risk of bankruptcy (Copeland \& Weston, 1992). Managers, for job-security reasons, are also affected in their decision to use debt by the firm's level of earnings stability. Stable earnings allow liberal use of debt, because the firm is capable of meeting its debt obligations as and when they fall due. Kim and Sorensen (1986) observed that firms with a high degree of business risk have less capacity to sustain financial risks, and thus use less debt. It is hypothesised therefore that risk is negatively related to bank debt ratio.

Growth is also measured by market to book value. According to Marsh (1982), firms with high growth will capture relatively higher debt ratios. It is expected that firms with high growth opportunities will require more external financing to finance their growth and therefore should display higher leverage (Kester, 1986; Titman \& Wessels, 1988; Barton et al., 1989). Growth is predicted to be positively related to bank debt ratio.

Interest rate and inflation are included to capture the effect of macro-economic conditions on bank borrowing. It is expected that firms would be deterred from borrowing during periods of high interest and inflation rates.

\subsection{The empirical model}

This study adopts a panel regression because it combines the cross-sectional data with timeseries data. The analytical model considers the relationship between bank debt ratio and age of firm, size of the firm, asset structure, profitability, firm risk, growth opportunities, interest rate and inflation. The model for the empirical investigation is given as follows:

$B D R_{i t}=\beta X_{i t}+\delta_{i}+\mathrm{y}_{t}+\varepsilon_{i t} \ldots \ldots .1$

where $B D R$ is the bank debt ratio, $X$ represents the independent variables, subscript $i$ and $t$ represent the firm and time, respectively, and $\delta, y$, and $\varepsilon$ represent the firm-specific effects, time-specific effects, and the stochastic term in the equation.

\section{4 \\ Results}

\subsection{Descriptive statistics}

Table 1 provides a summary of the dependent and independent variables. It reports the mean statistics for attributes of the firms included in the sample. Firm age has a mean (median) age of 37.6 (40). Size has a mean (median) of 17.663 (17.5663). Asset structure has a mean (median) of $0.4296(0.4723)$. This indicates that, on average, tangible fixed assets account for 42.96 per cent of total assets. Profitability indicates a mean value of 0.0908 , suggesting a return on assets of 9.08 per cent. Risk shows a mean 
(median) of $0.0556(0.0448)$. The mean growth (measured as market-to-book value) is shown as 5.8756. This indicates an average market-tobook value ratio of approximately 5.88 during the five-year period. Average interest and inflation rates were 40.41 per cent and 21.42 per cent respectively.

Table 1

Descriptive statistics of dependent and independent variables

\begin{tabular}{|l|c|c|c|c|c|}
\hline Mean & Mean & Std. Dev. & Minimum & Median & Maximum \\
\hline Bank debt ratio & 0.3365 & 0.6562 & 0.0012 & 0.1440 & 0.7130 \\
\hline Age & 37.6470 & 18.6073 & 6.0000 & 40.0000 & 71.0000 \\
\hline Size & 17.6683 & 1.2559 & 15.3747 & 17.5663 & 20.0551 \\
\hline Asset structure & 0.4296 & 0.1876 & 0.0347 & 0.4723 & 0.6945 \\
\hline Profitability & 0.0908 & 0.1079 & -0.1408 & 0.0496 & 0.3500 \\
\hline Risk & 0.0556 & 0.0498 & 0.0010 & 0.0448 & 0.2215 \\
\hline Growth & 5.8756 & 5.9561 & 0.3885 & 3.5714 & 30.3346 \\
\hline Interest & 0.4041 & 0.0472 & 0.3000 & 0.4200 & 0.4800 \\
\hline Inflation & 0.2142 & 0.7563 & 0.1240 & 0.1920 & 0.3200 \\
\hline
\end{tabular}

With respect to our investigation of the listed companies' reliance on bank borrowing, the financial statements identified explicitly the aggregate amount of total debt employed by the firms as well as the amount that is made up of bank borrowing. The reported figures only reflect loans which are actually outstanding and do not take into account undrawn loan commitments. Although the amount of nonbank debt is not reported, it could be inferred by deducting the amount of bank debt from total debt outstanding. The mean bank debt ratio is 0.3365 . This suggests that, on average, about one-third of the firm's outstanding debt is obtained from banks. The results generally suggest that bank financing is an important source of debt finance for the listed firms. On the whole, bank financing is a significant source of financing Ghanaian listed firms, considering that debt constitutes more than half of their total assets (see Abor \& Biekpe, 2005).

\subsection{Panel regression results}

Regression analysis is used to estimate the effect of each independent variable on the bank debt ratio. The Ordinary Least Squares (OLS) panel was found to be the most robust after testing for various options of the panel data regression such as Fixed Effects and Random Effects. The results of the OLS panel regression corrected with White heteroscedastic-consistent standard errors are presented in table 2 . The results from the model denote that the independent variables explain the bank debt ratio determination of the firms at 68.5 per cent. The F-statistics further justify the joint significance of all the explanatory variables in the model. 
Table 2

Regression model results

\begin{tabular}{|l|c|c|c|c|}
\hline Variable & Coefficient & Std. Error & T-statistic & Prob. \\
\hline Constant & 1.664991 & 0.224628 & 7.412203 & 0.0000 \\
\hline Age & -0.002657 & 0.001458 & -1.821678 & 0.0756 \\
\hline Size & -0.191093 & 0.018720 & -10.20797 & 0.0000 \\
\hline Asset structure & 0.258909 & 0.086640 & 2.988320 & 0.0047 \\
\hline Profitability & -1.400852 & 0.291711 & -4.802194 & 0.0000 \\
\hline Risk & -0.865500 & 0.221847 & -3.901336 & 0.0003 \\
\hline Growth & 0.022453 & 0.003267 & 6.872672 & 0.0000 \\
\hline Interest & 4.932630 & 0.472305 & 10.44373 & 0.0000 \\
\hline Inflation & 0.119161 & 0.162736 & 0.732237 & 0.4681 \\
\hline R-squared & & 0.685023 & \\
\hline Adjusted R-squared & & & 0.625027 \\
\hline S.E. of regression & & & \\
\hline F-statistic & & & \\
\hline Prob (F-statistics) & & & \\
\hline
\end{tabular}

Contrary to the hypothesis of a positive relationship, the empirical results show that age has a significantly negative relationship with the bank debt ratio. Newly established firms are constrained in their ability to raise funds from the public capital markets owing to their lack of track record. They therefore do not have other alternatives but to borrow from banks initially. It is assumed that older firms, in terms of how long they have been in business, tend to be more reputable than newly established businesses. With time, however, as the firms acquire a good track record, they switch to raising funds from the public market. Also, older firms have most likely achieved a wellestablished source of internal equity and are therefore expected to have lower debt. Similarly, the negative relationship between firm size and bank debt reliance is consistent with the argument that the delegated monitoring of banks is less valuable to large firms since they are already monitored closely by market analysts. The results indicate that as firms increase in size, they depend less on bank loans and more on internal sources of finance and the capital market. Larger firms thus employ less bank debt in their capital structure. The findings provide support for some empirical studies (see Fama, 1985; Diamond, 1991; Slovin et al., 1992; Houston \& James, 1996; Johnson, 1997; Ooi, 2000). According to Fama (1985) and Diamonds (1991), screening and monitoring benefits associated with bank loans are enjoyed primarily by the smaller and less prestigious firms. Larger firms are able to raise more equity capital at relatively lower cost (larger firms enjoy economies of scale with respect to floatation costs). In contrast, small firms do not have much choice other than to rely on bank debt for their external funding. This position also contradicts our expectation of a direct relationship.

The results indicate a statistically significant positive relationship between asset structure and bank debt ratio. The empirical evidence suggests that firms use tangible fixed assets as collateral when negotiating borrowing, especially long-term bank borrowing. Listed firms that maintain a large proportion of fixed assets in their total assets tend to have easier access to bank loans than those that do not. Firms that invest heavily in tangible assets are also likely to borrow at lower interest rates if their debt is secured with such assets. This result also supports the position by Titman and 
Wessels (1988). The results of this study also show a significantly negative relationship between profitability and bank debt ratio, suggesting that firms that generate internal funds generally tend to avoid gearing. The findings provide support for the pecking order theory that denotes that profitable firms prefer internal financing to external financing. The significantly negative impact of risk implies that firms that perform below average are less leveraged and are less likely to depend on bank borrowing. High-risk firms generally find debt less attractive because of the associated financial risk. The empirical results show a significantly positive association between growth opportunities and bank debt ratio. Firms with high growth potentials generally require more external funds to finance their growth opportunities. This study uses the market-tobook value as a proxy for the firm's growth opportunities. It could be argued that firms with good growth prospects are deemed as good investment avenues for banks. The findings for asset structure, profitability, risk, and growth opportunities are consistent with our hypotheses.

With respect to the macro-economic variables, only the interest rate is significant in the regression, indicating a positive relationship with bank debt ratio. The results show that banks would grant more credit with increased interest rates. Firms with existing bank debt therefore borrow at higher cost. The results suggest that firms with outstanding bank loans in their debt portfolio are perceived as having high credit risk. Thus, banks would be willing to grant fresh loans to such firms at higher interest rates.

\section{5 Summary and conclusion}

This study examined the incidence of bank financing among listed companies and the determinants of listed firms' reliance on bank borrowing during a five-year period, viz.19982002. The empirical results revealed that bank loans account for one-third of total debt financing of listed firms in Ghana. This suggests that listed firms rely on some bank loans in addition to funds raised from the stock market. The results of this study also show that asset structure, growth opportunities and interest rate have significantly positive associations with bank debt ratio, while age of the firm, size of the firm, profitability and firm risk are significantly and negatively related to bank debt ratio. The results of this study clearly indicate that listed firms that maintain a large proportion of tangible fixed assets in their total assets are more likely to have easier access to bank loans and those with growth opportunities tend to require more external funding to finance their growth. Also, firms with existing bank debt borrow at higher cost. The results of this study also suggest that older, larger, profitable and high-risk companies are less likely to depend on bank loans. With respect to the negative associations, the results suggest that older and larger firms are able to raise more equity capital at relatively lower cost (larger firms enjoy economies of scale with respect to floatation costs). In contrast, small firms do not have much choice other than to rely on bank debt for their external funding. Firms that generate adequate internal funds generally tend to avoid gearing. High-risk firms also find debt less attractive and therefore are less likely to rely on bank borrowing.

Although most theoretical models combined bank loans and non-bank private debt into one category under private debt, this study shows that bank loans account for one-third of debt financing of Ghanaian listed firms. The study has offered some economic rationale from corporate finance literature on the economic role of bank loans in financing firms. The results generally indicate that bank financing continues to play an important role in the financing decisions of Ghanaian listed firms.

\section{References}

1 ABOR, J. \& BIEKPE, N. (2005) "What determines the capital structure of listed firms in Ghana?", African Finance Journal, 7(1): 37-48.

2 ARYEETEY, E. (2001) "Strengthening Ghana's financial market: An integrated and functional approach”, ISSER, Millennium Seminar Series 
No.6, Institute of Statistical, Social and Economic Research, University of Ghana, Legon.

3 AGARWAL, S. \& MOHTADI, H. (2004) "Financial markets and the financing choice of firms: Evidence from developing countries", Global Finance Journal, 15:57-70.

4 ASQUITH, P. \& MULLINS, JR. D.W. (1986) "Equity issues and offering dilution", Journal of Financial Economics, 15:61-89.

5 BARTON, S.L.; NED, C.H. \& SUNDARAM, S. (1989) "An empirical test of stakeholder theory predictions of capital", Financial Management, 18(1):36-44.

6 BERLIN, M. \& LOYES, J. (1988) "Bond covenants and delegated monitoring", Journal of Finance, 43:397-412.

7 BERLIN, M. \& MESTER, L. (1992) "Debt covenants and delegated monitoring", Journal of Finance, 43:397-412.

8 BESTON, G.J. \& SMITH, C.W. (1996) "A Transaction cost approach to the theory of financial intermediation", Journal of Finance, 31:215-231.

9 BLACKWELL, D. \& KIDWELL, D. (1988) "An investigation of the cost differences between public sales and private placements of debt", Journal of Financial Economics, 22:253-278.

10 BOYD, J. \& PRESCOTT, E.C. (1986)

"Financial intermediary-coalitions", Journal of Financial Theory, 38:211-232.

11 BRADLEY, M.; JARREL, G.A. \& KIM, E.H. (1984) "On the existence of an optimal capital structure: Theory and evidence", The Journal of Finance, 39:857-880.

12 BROWN, D. T.; JAMES, C.M. \& MOORADIAN, R.M. (1993) "The Information content of distressed restructurings involving public and private debt claims", Journal of Financial Economics, 33:93-118.

13 BUCHS T. \& MATHISEN, J. (2003) "Banking competition and efficiency in Ghana, Institute of Statistical”, Social and Economic Research and Cornell University International Conference on Ghana at the Half Century, July 18-20, 2004.

14 CAMPBELL, T.S. (1979) "Optimal investment financing decisions and the value of confidentiality", Journal of Financial and Quantitative Analysis, 14:913-924.

15 CAMPBELL, T.S. \& KRACAW, W.A. (1980) "Information production, market signalling, and the theory of financial intermediation", Journal of Finance 35:863-882.

16 CANTILlO, M. \& WRIGHT, J. (2000) "How do firms choose their lenders? An empirical investigation", Review of Financial Studies 13:155-189.

17 CHEMMANUR, T. \& FULGHIERI, P. (1994) "Reputation, renegotiation, and the choice between bank loans and publicly traded debt", Review of Financial Studies 7:475-506.

18 COPELAND, T.E. \& WESTON, J.F. (1992) Financial Theory and Corporate Policy, 3rd ed., Addison-Wesley.

19 DIAMOND, D.W, (1984) "Financial intermediation and delegated monitoring", Review of Economics Studies, 51:393-414.

20 DIAMOND, D.W. (1989) "Reputation acquisition in debt markets", Journal of Political Economy, 97:828-62.

21 DIAMOND, D.W, (1991) "Monitoring and reputation: The choice between bank loans and directly placed debts", Journal of Political Economy, Issue 99(4):689-721.

22 ECKBO, B.E. (1986) "Valuation effects of corporate debt offerings", Journal of Financial Economics, 15:19-151.

23 FAMA, E.F. (1978) “The effects of a firm's investment and financing decisions on the welfare of its stockholders", American Economic Review, 68:272-284.

24 FAMA, E.F. (1985) "What's different about banks?", Journal of Monetary Economics, 15:2939.

25 GERTNER, R. \& SCHARFSTEIN, D. (1991)

"A theory of workouts and the effects of reorganisation law", Journal of Finance, 46:1189-1222.

26 HARRIS, M. \& RAVIV, A. (1990) "Capital structure and the informational role of debt", Journal of Finance, 45(2):321-349.

27 HARRIS, M. \& RAVIV, A. (1991) "The theory of capital structure", Journal of Finance, 46(1):297-355.

28 HOUSTON, J. \& JAMES, C. (1996) "Bank information monopolies and the mix of private and public debt claims", Journal of Finance, 51(5):217-235.

29 JAMES, C. (1987) "Some evidence on the uniqueness of bank loans", Journal of Financial Economics, 19:217-235.

30 JENSEN, M. \& MECKLING, W. (1976) "Theory of the firm: managerial behavior, agency costs and ownership structure", Journal of Financial Economics, 3:305-360.

31 JOHNSON, S.A. (1997) "An empirical analysis of the determinants of corporate debt ownership structure", Journal of Finance and Quantitative Analysis, 21(1):47-69. 
32 KESTER, W.C. (1986) "Capital and ownership structure. A comparison of United States and Japanese manufacturing corporations", Financial Management, 15:5-16.

33 KIM, W.S. \& SORENSEN, E.H. (1986) "Evidence on the impact of the agency costs of debt on corporate debt policy", Journal of Financial and Quantitative Analysis, 21:131143.

34 KRISHNASWAMI, S.; SPINDT, P.A. \& SUBRAMANIAM, V. (1999) "Information asymmetry, monitoring and the placement structure of corporate debt", Journal of Financial Economics, 51:407-434.

35 KWAN, S.H. \& CARLETON, W.T. (1995) “The role of private placement debt issues in corporate finance", Federal Reserve Bank of San Francisco, Working Paper.

36 LELAND, H.E. \& PYLE, D.H. (1977) "Informational asymmetries, financial structure, and financial intermediation", Journal of Finance 32:371-387.

37 LUMMER, S.L. \& MCCONNELL, J.J. (1989) "Further evidence on the bank lending process and the capital market response to bank loan agreements", Journal of Financial Economics, 25:99-122.

38 MARSH, P. (1982) "The choice between equity and debt: An empirical study", Journal of Finance, 37(1):121-144.

39 MIKKELSON, W. \& PARTCH, M. (1986) "Valuation effects of securities offerings and the issuance process", Journal of Financial Economics, 15:31-60.

40 MILLER, M.H. (1977) "Debt and taxes", Journal of Finance, 32:261-276.

41 MODIGLIANI, F. \& MILLER, M. (1963) "Corporate income taxes and the cost of capital: A correction", American Economic Review, 53:443-453.
42 MYERS, S.C. (1984) "The capital structure puzzle", Journal of Finance, 39:575-592.

43 MYERS, S.C. \& MAJLUF, N.S. (1984) "Corporate financing and investment decisions when firms have information that investors do not have", Journal of Financial Economics, 12:187-221.

44 OOI, J. (2000) "Corporate reliance on bank loans: an empirical analysis of U.K. property companies", Journal of Property Investment and Finance, 18(1):103-120.

45 RAJAN, R. (1992) "Insiders and outsiders: the choice between informed and arm's-length debt", Journal of Finance, 47:1367-1406.

46 ROSE, P.S. (1999) Commercial Bank Management, Irwin Macgraw Hill, 4:616.

47 SLOVIN, M.B.; JOHNSON, S.A. \& GLASCOCK, J.L. (1992) "Firm size and the information content of bank loan announcements", Journal of Banking and Finance, 16:1057-1071.

48 TITMAN, S. \& WESSELS, R. (1988) "The determinants of capital structure choice", Journal of Finance, 43(1):1-19.

49 WALD, J.K. (1999) "How firm characteristics affect capital structure: An international comparison", Journal of Financial Research, 22:161-187.

\section{Endnotes}

1 This study draws from ongoing research funded by the African Economic Research Consortium, whose financial support is acknowledged. The author is grateful to the resource persons and peers of thematic research group C (AERC) for comments on the main research work. 